症例

SLE による血管炎が原因と考えられた胆囊出血の 1 例

慶應義塾大学一般消化器外科, 慶應義塾大学病理学教室*
萩生田
純 河 地 茂 行
亀山香 織* 北島 政 樹

症例は39歳, 女性. 23歳時に SLE と診断されていた. 1 力月前より SLE の活動性が 上昇し PSL を増量していた. 6 日前より自覚していた心墖部痛が増強したため当院救急 外来を受診した. 右上腹部に限局した圧痛と反跳痛を認め, WBC $10,800, \mathrm{CRP} 2.2$ と軽 度炎症反応を認めた。腹部 CT 上, high と low density area の混在した胆薄内容を認め, 超音波では debrisで緊満した胆裂を認めた。 入院後疼痛が堌強し, 腹部全体の筋性防御 も出現し, 汎発性腹膜炎と考えられたため同日緊急手術を施行した. 手術所見では, 腹 腔内の大量の凝血塊および血性腹水, また胆裂内に充満した凝血塊を認め, 胆蘘摘出術,

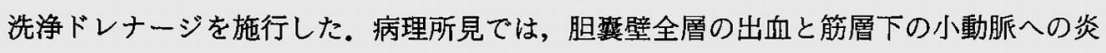
症性細胞浸潤, EVG 染色にて内弾性板の破壊像を認め, SLE による血管炎の増悪に伴う 胆䔩出血と考えられた，膠原病に伴う血管炎を基盤とした胆蔃出血は極めて稀であり， 若干の文献的考察を加えて報告する。

索引用語：胆徱出血, SLE

\section{緒 言}

胆襄出血は様々な原因を背景に, 腹痛, 消化管出血 や黄㾝で発症する極めて稀な疾患である。.今回われわ れはSLEによる血管炎が原因であると特定された胆 襄出血の 1 例を経験したので若干の文献的考察を加え て報告する。

\section{症 例}

症例：39藏, 女性.

主訴: 右季助部痛, 心窩部痛.

既往歴：23歳時より SLE を発症.31歳時に右大腿骨 頭置換術, 33歳時に左大腿骨頭置換術を受け, その頃 より人工透析を導入された。

現病歴：2002年10月より SLE の活動性が上昇し,ス テロイド(プレドニン)を 1 日 $5 \mathrm{mg}$ から $10 \mathrm{mg}$ に増量 していた。11月22日より心窩部痛を自覚していたが29 日になり急激に腹痛が増恵し, 当院救急外来を受診し そのまま入院となった。

入院時現症：眼瞼・眼球結膜に貧血, 黄疸なし. 右 季助部に圧痛および軽度筋性防御を認めた。

2004年 4 月 1 日受付 2004 年 5 月 7 日採用

〈所属施設住所〉

干160-8582 東京都新宿区信濃町 35
入院時検查 : WBC $10,800 / \mu \mathrm{l}, \mathrm{CRP} 2.2 \mathrm{mg} / \mathrm{dl}$ と軽 度上昇. また $\mathrm{Hb} 10.5 \mathrm{~g} / \mathrm{dl}$ と軽度實血を認めた. BUN $43.5 \mathrm{mg} / \mathrm{dl}, \mathrm{Cr} 6.3 \mathrm{mg} / \mathrm{dl}$ と腎機能異常を認めたが肝 機能, 胆道系醉素, 黄疸值は正常であった。

腹部超音波検査：胆瞢は緊满し, 内腔には大部分が hyperechoic な debris 様の胆震内容が充満していた。 胆石や胆襄周囲の腹水, 膿瘍は明らかでなく, 壁肥厚

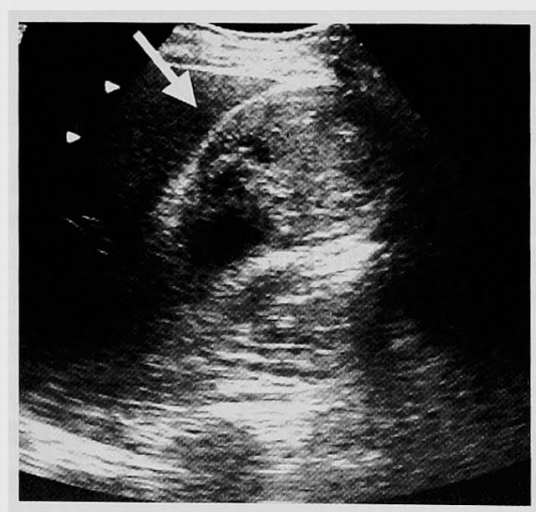

図 1 腹部超音波：胆蒦は緊満し，内腔には 大部分が hyperechoic な debris 様の胆琵 内容が充満していた。 


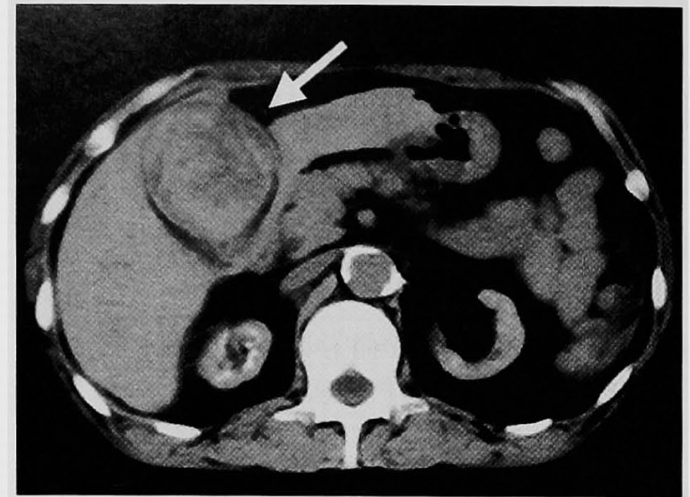

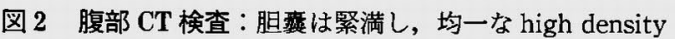
area の中に low density area の混在した内容物を認め た.

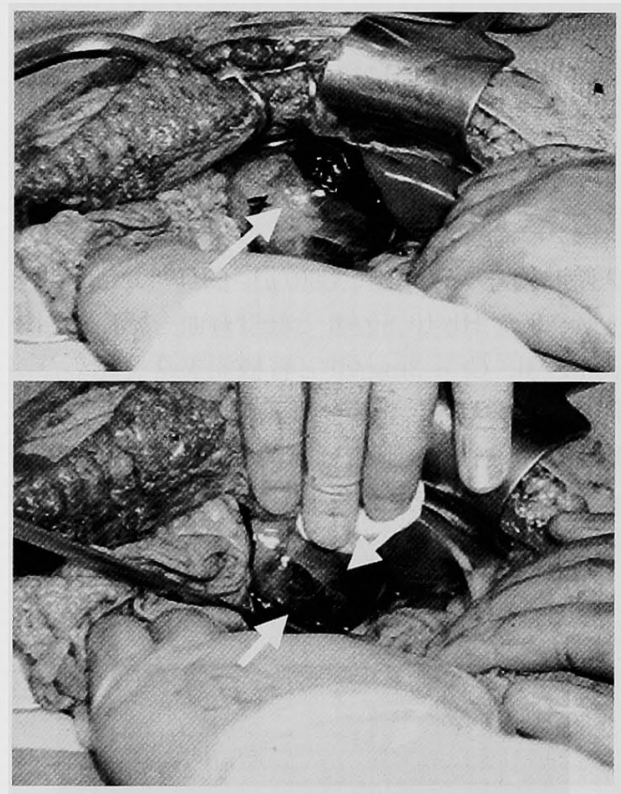

図 3 手術所見：a）腹腔内に大量の凝血塊および 血性腹水を認めた. b ) 緊満した胆露体部の奬膜に 裂傷を認め, 腹腔内出血の出血源と考えられた.

\section{も軽度であった（図 1 ).}

腹部 CT 検查 : 胆顀は緊満し, 壁肥厚は軽度で, 均一 な high density area の中に low density area の混在 した内容物を認めた(図 2 ). 胆石や腫場, 胆要周囲膿 瘍などは認めなかった。

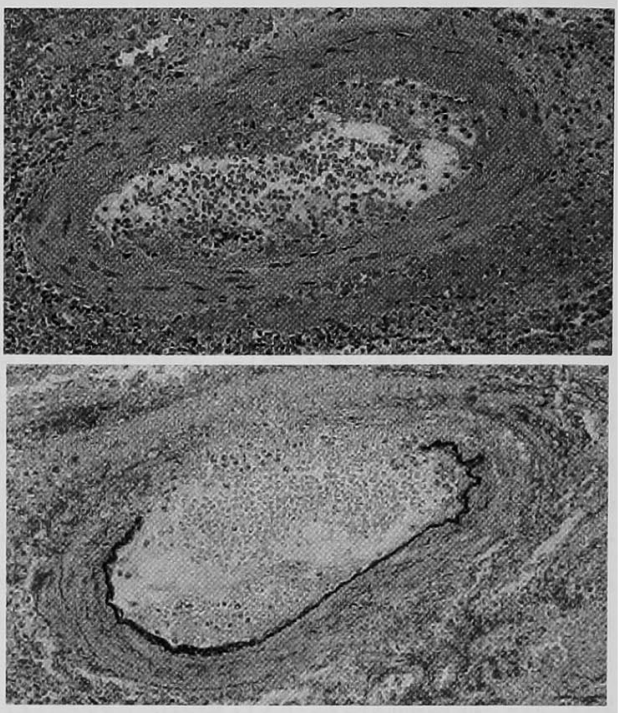

図 4 病理組織学的所見：a ) 壁内の細動脈に著明な 炎症性細胞浸潤を認めた（HE 染色 $\times 400 ） ， b)$ 内 弾性板の破壊像が認められ,血管炎に典型的な所見 を呈していた（EVG染色 $\times 400 ）$.

$\frac{\mathrm{a}}{\mathrm{b}}$

入院後, 右季助部痛は次第に腹部全体に広がり，広 範に筋性防御，反跳痛を認めるようになった，圧痛は 右季肋部が最強で, 画像所見でも明らかな胆霊の異常 があることから，何らかの原因で発症した急性胆萁炎 が急速に腹部全体に波及し，汎発性腹膜炎をきたして いると考え，PTGBDなどの手術以外の手段では対処 不可能と判断し, 同日緊急手術を施行した。手術法と しては, 汎発性腹膜炎で, 胆雚炎の原因は不明であり, 術中胆道造影や総胆管に対するアプローチの必要性も あると考え腹腔鏡下にはこだわらず,開腹を選択した。

手術所見：上腹部正中切開にて開腹すると腹腔内に 大量の凝血塊抢よび血性腹水を認めた。緊満した胆㖶 体部の漿膜に裂傷があり持続的な出血がみられ腹腔内 出血の出血源と考えられた．胆襄壁は菲薄化しており 容易に裂け，胆露内には凝血塊が充満していた。何ら かの原因で䏣襄内に出血し，それにより緊満した胆裏 が裂傷をきたし，腹腔内出血を起こしたものと考えら れた（図 3 ).

胆摘後に術中胆道造影を施行したが総胆管内の胆汁 は色・性状とも問題なく，造影所見も血腫や石などの 異常を認めず，総胆管内には出血が波及していないと 判断した．摘出した胆䟰には凝血の付着はあるものの 
表 1 胆謱出血に関する自験例を含む過去10年間の本邦報告例（最上段は自験例）

\begin{tabular}{|c|c|c|c|c|c|c|c|c|}
\hline 年齢 & 性别 & 腹痛 & 黄疸 & $\begin{array}{c}\text { 消化管 } \\
\text { 出血l }\end{array}$ & 術前診断 & 術前診断の根樾 & 治療 & 背筀疾患・原因 \\
\hline 39 & $\mathrm{~F}$ & + & - & - & 急性䏣炎 - 汎発性腹膜炎 & $\mathrm{CT}, \mathrm{US}$ & 㗨急・逐摘 & SLE - 血管炎, 透析 \\
\hline $69^{3)}$ & $\mathrm{F}$ & + & - & - & 急性胆覜炎 & CT, US & 待機・胆摘 & なし \\
\hline $66^{4}$ & M & + & - & + & 急性出血性胆䟞炎 & $\overline{C T}$ & 㗨急・胆摘 & 虚血性心疾患 \\
\hline $74^{51}$ & $\mathrm{~F}$ & + & - & + & 胆覆内出血 & CT, US, Angio & 待機 - Lap -C & 胆露仮性動脈瘤？ \\
\hline $44^{6)}$ & $\mathrm{F}$ & + & - & - & 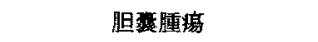 & $\mathrm{CT}, \mathrm{US}$ & 待機・胆摘 & 腎移植後, CMV感染? \\
\hline $40^{7}$ & $\mathrm{~F}$ & + & + & + & 急性出血性胆要炎 & PTGBD & 待機 - Lap-C & SLE, 透析 \\
\hline $53^{3)}$ & $\mathbf{M}$ & + & + & - & 急性胆震炎 & CT, US & $\begin{array}{c}\text { 祭急・胆摘, } \\
\text { T-tube洀入 }\end{array}$ & 痛風婜, 透析 \\
\hline $53^{9)}$ & M & + & + & + & 念性出血性胆垔炎 & PTGBD & 待譏 - 胆摘 & なし \\
\hline $78^{101}$ & $\mathrm{M}$ & + & - & - & 急性出血性胆震谈 & $\begin{array}{l}\mathrm{CT}, \mathrm{US}, \\
\text { 抗凝固療法中 }\end{array}$ & $\begin{array}{c}\text { 待機・胆摘, } \\
\text { T-tube挿入 }\end{array}$ & 開心遇後18日, 抗凝固療法中 \\
\hline $72^{111}$ & F & + & + & + & 急性出血性胆䡤炎, 胆道出血 & PTGBD & $\begin{array}{l}\text { 待機・胆摘, } \\
\text { T-tube挿入 }\end{array}$ & 胆石 \\
\hline $91^{12)}$ & $\mathrm{F}$ & + & + & - & 急性出血性胆蒦炎 & $\mathrm{CT}$ & 嶨急・胆摘 & 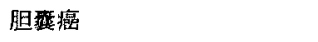 \\
\hline $28^{131}$ & M & + & - & - & 無石胆裹炎 & $\mathrm{CT}, \mathrm{US}$ & 待機・䢸摘 & 再生不良性䆩血, 㲸血球減少 \\
\hline
\end{tabular}

表 2 胆雯出血の原因と考えられる背景（最上段は自験例）

\begin{tabular}{|c|c|c|c|c|c|c|}
\hline 年䶜 & 胆石 & 膠原病 & 透折 (楚) & 薬閒 & 他 & 原因不明 \\
\hline $39^{*}$ & & SLE & 0 & PSL10mg & 䘏管资あり & \\
\hline $69^{33}$ & & & & & & 0 \\
\hline $66^{4}$ & & & & & 心筇梗塞，高血厓 & \\
\hline $74^{53}$ & & & & & 胆萑仮性動脈䊩 & \\
\hline $44^{6)}$ & & SLE & $\mathrm{O}$ & CyA, PSL & 腎移植後, CMV感染? & \\
\hline $40^{n}$ & & SLE & 0 & PSL20mg, 抗凝固郕 & & \\
\hline $53^{81}$ & & & 0 & & 痛圆腎 & \\
\hline $53^{9 !}$ & & & & & & 0 \\
\hline $78^{109}$ & & & & 抗凝固剂 & 開心術後 & \\
\hline $72^{11}$ & 0 & & & & & \\
\hline $91^{(2)}$ & & & & & 肽霆癌 & \\
\hline $28^{13)}$ & & & & PSL10mg & 再生不良性覥血, 沉血球減少 & \\
\hline
\end{tabular}

肉眼的に明らかな腫漡や壁肥厚は存在せず, 潰場形成 も認めず出血の部位を特定するのは困難であった，胆 石も認めなかった。

病理組織学的所見：胆㖶壁全層にわたる広範な出血 と共に粘膜から筋層にかけての高度の好中球浸潤が認 められた．炎症性細胞浸潤は特に筋層・槳膜下層の小 動脈周囲に目立ち,EVG 染色ではこの部位の小動物に おける内弾性板の破壊像が散見され，壊死性血管炎に
典型的な所見を呈していた(図 4)。これら病理学的所 見から本症例がSLEの增悪に伴う血管炎による胆鋉 出血との診断を得た。

術後経過：術後 7 日目に遅発性の胆汁漏をきたし再 手術を施行した。創感染をきたしたもののその後は順 調に経過し原疾患の治療も含めて60病日で軽快退院し た. 


\section{考 察}

胆整出血牥様々な原因を背景に，腹痛で発症し，胆 道出血を伴った場合，黄疸や消化管出血をきたす極め て稀な疾患である。検查が十分出来ない緊急例や黄㾝， 吐下血などの出血症状を認めない症例では猃断が困難 なことが多く，治療としては胆慗摘出術が第一選択と なる。

盟頳出血の初報告例は欧米では1948年のSandb-

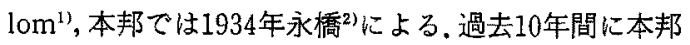
においては自験例を含めて12例の報告があった

(表 1 ). 症状としては全例に腹痛を認め, 半数以上に 黄疸や消化管出血伴っていた。術前猃断の可能であ つた症例は, 胆道出血, 消化管出血をきたした症例や， 繰り返し㭘查が可能であった待機手術症例に限られ, 緊急でかつ出血症状のみられなかった症例では正確な 術前診断が得られたものは皆無であった。

胆㖶出血の亳断にはエコー, CT な゙の画像診断が 重要で, 大部分が hyperechoic な debris 様の胆栾内容 の充満を呈するエコー像, 均一な high density area の 中に low density areaの混在した胆集内容を呈する CT 像が文献的に特徽的な所見と考えられる.

本症例は腹痛が㩆著であったが黄疸, 出血症状はな く, 入院時の血液検查所見では WBC, CRP の上昇の みで, 肝機能・胆道系醇菜は正常であった。また画像 検查所見では胆酸の異常所見以外, 胆管系の拡張・出 血などを示唆する所見はなく, 胆巽炎が急速に進展し 汎発性腹膜炎になったと考えた。しかし retrospective

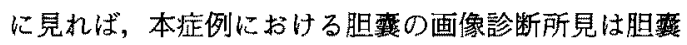
内血腫を示唆する特徵的な所見を有しており，この様 な疾患が念頭にあるかどうかが術前診断の鍵になるも のと思われた。

治療は胆管切開を必要としたものが 3 例あり, 待機 例の 2 例で腹腔鏡下胆嘎摘出術が施行されているが他 は開腹胆等摘出術が施行されていた，本症例も術中胆 管造影で胆管内の異常所見がなかったため，胆摘のみ で手術を終了した。

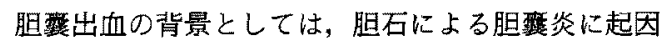
するものは少なく，膠原病の合併が 3 例，ステロイド の内服が 4 例，血液透析中が 4 例と compromised な 患者に頻度が高い（表 2 ）。胆蕒出血をきたす理由は 個々の症例で樣々な要因が絡み合っていると考えられ るが，これらの背景を持つ患者の急性腹症に注本症例 を念頭に置く必要があると考えられた。

本症例は病理学的に壊死性血管炎の所見を呈し，血
管炎により破壊された多数の小動脈から壁内へ出血 し, 胆翼内から壁外入出血が進展したものと考えられ た，血管炎の原因としては胆蟹由来の結節性多発動脈 炎 (PN) も否定できないが，患者の背景疾患から考え てSLEによる血管炎と考えるのが妥当と思われた。䏣 裂出血の原因，部位が特定されることは非常に稀で， 本症例のように膠原病による血管炎が原因と特定され た報告はなく，非常に貴重な症例と考えられた。

\section{結 語}

SLE の血管炎が原因と考元られた胆蘘出血の 1 例

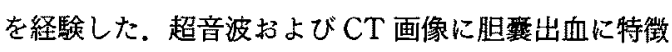
的な所見があった。また本疾患は血液透析中や膠原病 などを合併した患者の急性腹症の原因として念頭に置 くべき疾患であると考えられた。

\section{文献}

1) Sandblom $P$ : Hemorrhage into the biliary tract following trauma-"Traumatic Hemobilia". Surgery $24: 571-586,1948$

2) 永橋正利：急性出血性胆萭炎の1例. 九州医会誌 $36: 382-384,1934$

3）松本秀一朗, 安念和哉, 田口宏一他：急性出血性 胆露炎のI例。砂川病医誌 $19: 43-45,2002$

4）花城徳一, 石川正志, 佐々木賢二他：急性出血性 胆漠炎の1例.日踟外会誌 $61: 2739-2742,2000$

5）三浦光一, 星野孝男, 小松演史他：胆酸仮性動脈 瘤破裂によると考えられた胆菫出血の 1 例. 日消 病会誌 $95: 450-454,1998$

6）西村 渉, 堀見忠司, 長田裕典他：腎移植後, 緊 急手術を施行した胆鲧出血の 1 例。移植 $32: 174$ $-179,1997$

7) 久保晋吾, 田滇一郎, 宮原妙子他：出如性胆囊炎

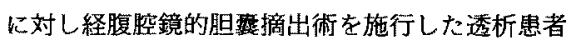
の1 例. 督と透析 $43: 891-894,1997$

8）林 春幸, 吉田正美, 小林 進他: 慢性血液透析 患者に発症した䏣薙出血の 1 治験例. 日透析医学 会誌 29：149-153，1996

9）大野一登, 恒川謙吾, 伊藤拨雄他：胆露出血の 1 例。臨今治 $10: 5-7,1995$

10）寺西克仁，村瀬允也，前田正信他：開心術後抗㠜

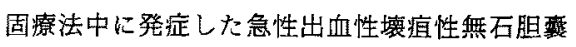
炎, 胆汁性腹膜炎の 1 例. 日胸外会誌 $41: 83$ 87,1993

11）坂本洋一, 松毛真一, 高橋康幸: 胆漖炎以起因す る胆襄出血の 1 例.日消外会誌 $25: 2388-2392$, 
1992

12）宇田慧司, 難波康夫, 藤原恒弘地：急激な胆褒内 出血により発芫された胆藻癌の1例。広島医 $45: 603-605,1992$
13）山本真也，河本知二，久米川辟他：重症再生不良 性貟血患者の胆雚摘除術の 1 例一術前 $\gamma$-グロブ リン大量投与による出血抑制の効果一。日臨外医 会誌 $53: 563$ - 566,1992

\title{
A CASE OF GALLBLADDER BLEEDING PROBABLY CAUSED BY ANGITIS DUE TO SYSTEMIC LUPUS ERYTHEMATOSUS
}

\author{
Jun HAGIUDA, Shigeyuki KAWACHI, Kaori KAMEYAMA* and Masaki KITAJIMA \\ Departments of Surgery and Pathology*, Keio University School of Medicine
}

A 39-year-old woman who had been diagnosed as having systemic lupus erythematosus (SLE) at the age of 23 and had a one-month history of increased activity of SLE with increased PSL was seen at the emergency clinic because of intensifying epigastric pain which started 6 days earlier. On physical examination, there were localized tenderness and rebound soreness in the right upper quadrant of the abdomen. The WBC was 10,800 and $\mathrm{CRP}$ was 2.2 , showing mild inflammatory reaction. Abdominal CT scans revealed the contents of the gallbladder was composed of high and low density areas concomitantly. Ultrasonic study showed the gallbladder tightly filled with debris. After admission to the hospital the pain was aggravated and muscle guarding over the entire abdomen appeared. Generalized peritonitis was considered and an emergency surgery was carried out on the same day. During surgery, massive clots and bloody ascites in the abdomen and clots filled gallbladder were identified. Cholecystectomy and irrigation drainage were carried out. On pathological examination, bleeding from the full thickness of gallbladder wall, infiltration of inflammatory cells to small arteries under the muscular layer, and destroyed internal elastic lamella on EVG staining were noted. Gallbladder bleeding associated with aggravation of angitis due to SLE was considered.

Since gallbladder bleeding caused by angitis associated with collagen diseases rarely occurs, this case is reported together with some bibliographical review. 